\title{
PENGARUH KUALITAS JURUSAN TERHADAP KEPUASAN MAHASISWA SERTA DAMPAKNYA PADA LOYALITAS MAHASISWA BARU TAHUN AJARAN 2017 - 2018 PADA JURUSAN MANAJEMEN DAKWAH UNIVERSITAS ISLAM NEGERI AR-RANIRY BANDA ACEH
}

\author{
Cut devi maulidasari, Riznal Ahkyar \\ Universitas Teuku Umar; Meulaboh \\ Email : cutdevimaulidasari@utu.ac.id \\ email: riznalakhyar1990@gmail.com
}

\begin{abstract}
The purpose of this study was to determine the influence of the quality of majors on student satisfaction and their impact on the loyalty of students of the Department of Da'wah Management at the State Islamic University Ar-Raniry Banda Aceh. Data analysis is the process of simplifying data into a form that is easier to read and implement. The method chosen to analyze the data must be in accordance with the research pattern and the variables to be studied. This research uses Structural Equation Modeling (SEM) method with research tools or software in the form of Partial Least Square (PLS). From the research that has been done through observation and secondary data, it can be concluded that the quality of the department, student satisfaction and the loyalty of students of the Da'wah Management Department of the Ar-Raniry State Islamic University in Banda Aceh are still good. From the research that has been done, it can be concluded that the quality of the department affects student satisfaction, with a $t$ statistic value of 15,639. Furthermore, from the results of the tests that have been carried out, it can be concluded that the quality of the department affects the loyalty of students with a $t$ statistic value of 14,319. From the research that has been done, it can be concluded that student satisfaction affects student loyalty, with a t statistic value of 22,281. And finally From the results of the research that has been done it can be concluded that the hypothesis which states that the quality of majors affects student loyalty through student satisfaction with a statistical value of 4,555 .
\end{abstract}

Keywords: quality, satisfaction and loyalty 
Jurnal Bisnis dan Kajian Strategi Manajemen

Volume 2 Nomor 1, 2018

ISSN : 2614-2147

http://jurnal.utu.ac.id/jbkan

\section{PENDAHULUAN}

\section{Latar Belakang Masalah}

Pendidikan adalah usaha sadar dan terencana untuk mewujudkan suasana belajar dan proses pembelajaran agar peserta didik secara aktif mengembangkan potensi dirinya untuk memiliki kekuatan spiritual keagamaan, pengendalian diri, kepribadian, kecerdasan, akhlak mulia, serta keterampilan yang diperlukan dirinyadan masyarakat.

Perguruan Tinggi sebagai salah satu bagian penting dalam dunia pendidikan yang ikut bertanggung jawab dalam upaya mencerdaskan kehidupan bangsa dan memiliki peran yang sangat strategis untuk mengambil bagian dalam mengatasi permasalahan kualitas sumber daya manusia. Selain itu, perguruan tinggi juga merupakan salah satu lembaga pendidikan yang diharapkan mampu menjawab tantangan masa depan, mengingat semakin ketatnya persaingan di dunia kerja. Oleh sebab itu, para lulusan harus mempunyai pengetahuan dan kompetensi yang tinggi, untuk itu para lulusan harus mempersiapkan sejak di bangku kuliah (Yuliana, 2004).

Pada dasarnya setiap calon mahasiswa yang ingin melanjutkan pendidikan ke perguruan tinggi akan memilih jurusan yang sesuai dengan yang di inginkan dan diharapkan jurusan yang sesuai tersebut dapat membekali setiap mahasiswa dalam menghadapi tantangan masa depan.Banyaknya jurusan yang ditawarkan oleh setiap perguruan tinggi membuat sebagian calon mahasiswa menjadi bingung dalam memilih jurusan apa yang tepat dan sesuai dengan kemampuan yang mereka miliki. Kesalahan dalam memilih jurusan sering diakibatkan oleh minimya pengetahuan calon mahasiswa tentang jurusan yang akan mereka tuju, psikis yang masih labil sehingga memungkinkan mereka untuk ikut-ikutan dalam memilih jurusan, dan terakhir banyak dari mereka yang terjebak dengan nama jurusan yang dianggap bagus. Sebenarnya kesalahan dalam memilih jurusan dapat berdampak pada menurunnya loyalitas mahasiswa terhadap jurusan ketika mereka memasuki dunia kampus, akan sering timbul gejolak batin yang menganggap bahwa apa yang mereka tekuni selama ini tidak sesuai dengan keahlian dan kemauan yang mereka harapkan untuk masa depan. 
Jurnal Bisnis dan Kajian Strategi Manajemen

Volume 2 Nomor 1, 2018

ISSN : 2614-2147

http://jurnal.utu.ac.id/jbkan

Fenomena salah memilih jurusan sering dialami oleh mereka mahasiswa baru yang baru saja lulus sekolah, tidak terkecuali dengan mahasiswa tahun ajaran 2017 - 2018 jurusan Manajemen Dakwah UIN Ar- Raniry Banda Aceh. memasuki semester ke II, peneliti memperoleh data sebagai berikut:

Tabel 1. Perbandingan jumlah mahasiswa

\begin{tabular}{|c|c|}
\hline Semester & Jumlah mahasiswa \\
\hline $\mathrm{I}$ & 96 \\
\hline II & 67 \\
\hline
\end{tabular}

Dari data di atas dapat disimpulkan bahwa sebanyak 20\% (19 mahasiswa) tidak melanjutkan pendidikannya pada semester ke II. Berkurangnya jumlah mahasiswa pada semester ke II dilatarbelakangi oleh berbagai alasan, diantaranya takut jauh dari orang tua, tidak memiliki biaya, dan yang banyak adalah berhenti serta mencoba mendaftar pada universitas maupun jurusan lain pada tahun ajaran baru yang akan datang. Banyaknya mahasiswa yang berhenti maupun keluar dari jurusan manajemen dakwah diakibatkan oleh rendahnya loyalitas yang dimiliki oleh mahasiswa.

Secara harfiah loyal berarti setia, atau loyalitas dapat diartikan sebagai suatu kesetiaan. Kesetiaan ini diambil tanpa adanya paksaan, tetapi timbul dari kesadaran sendiri pada masa lalu. Sutisna (2003) mendefinisikan loyalitas adalah sikap menyenangi terhadap suatu merek yang dipresentasikan dalam pembelian yang konsisten terhadap merek itu sepanjang waktu. Sedangkan menurut Kotler dan Keller (2012) mengungkapkan loyalitas adalah komitmen yang dipegang secara mendalam untuk membeli atau mendukung kembali produk atau jasa yang disukai di masa depan meski pengaruh situasi dan usaha pemasaran berpotensi menyebabkan pelanggan beralih.

Dari pengertian menurut para ahli diatas dapat dikatakan bahwa mahasiswa yang loyal terhadap jurusannya tidak akan berpindah atau berhenti belajar pada jurusan yang dipilihnya dan terus bertahan sampai selesai serta akan mengenalkan jurusannya pada orang lain untuk menarik minat para calon mahasiswa baru yang akan masuk pada angkatan berikutnya. Tetapi, jika mahasiswa tersebut tidak loyal 
Jurnal Bisnis dan Kajian Strategi Manajemen

Volume 2 Nomor 1, 2018

ISSN : 2614-2147

http://jurnal.utu.ac.id/jbkan

terhadap jurusannya maka ia akan memlih berhenti dan tidak akan melanjutkannya lagi.

Menurunnya tingkat loyalitas mahasiswa juga dipengaruhi oleh tingkat kepuasan mahasiswa yang rendah. Rendahnya tingkat kepuasan ini dapat diakibatkan oleh kualitas dosen, sarana dan prasarana pendukung, maupun pelayanan administrasi yang diperoleh oleh mahasiswa.

Menurut Zeithaml dan Bitner (2000) definisi kepuasan adalah Respon atau tanggapan konsumen mengenai pemenuhan kebutuhan. Kepuasan merupakan penilaian mengenai ciri atau keistimewaan produk atau jasa, atau produk itu sendiri, yang menyediakan tingkat kesenangan konsumen berkaitan dengan pemenuhan kebutuhan konsumsi konsumen. sedangkan menurut Kotler (2014) kepuasan adalah perasaan senang atau kecewa yang muncul setelah membandingkan kinerja (hasil) produk yang dipikirkan terhadap kinerja (atau hasil) yang diharapkan.

Dari definisi tersebut dapat dikatakan apabila kinerja produk tidak sesuai dengan harapan mahasiswa dan bila harapan yang ditetapkan terlalu rendah, maka mahasiswa tersebut akan merasa tidak puas dan berujung kecewa, jika kinerja sesuai dengan harapan maka mahasiswa akan merasa puas, namun apabila kinerjaproduk melampaui harapan, maka mahasiswa akan merasa senang dan sangatpuas.

Selain faktor kepuasan, menurunnya loyalitas mahasiswa terhadap jurusan juga dipengaruhi oleh kualitas jurusan, minimnya tenaga pengajar tetap yang ahli dibidang ilmu manajemen ikut memberikan dampak pada menurunnya kepuasan mahasiswa dalam proses belajar.Selain itu, berkembangnya isu sulitnya mencari pekerjaan dan minimnya lowongan kerja yang meminta program studi manajemen dakwah juga ikut menjadi masalah bagi mereka untuk bertahan pada jurusan dan menimbang kembali bagaimana nasib mereka dimasa akan datang.

Kotler dan Keller (2012) menyatakan bahwa kualitas produk adalah kemampuan suatu produk untuk melaksanakan fungsinya, meliputi daya tahan, keandalan, ketepatan, kemudahan operasi dan perbaikan serta atribut bernilai lainnya. Kualitas jurusan merupakan hal penting yang harus diusahakan oleh 
Jurnal Bisnis dan Kajian Strategi Manajemen

Volume 2 Nomor 1, 2018

ISSN : 2614-2147

http://jurnal.utu.ac.id/jbkan

setiap lembaga pendidikan jika ingin yang dihasilkan dapat bersaing dalam menciptakan sumber daya manusia yang berkompeten dibidangnya dan mampu bersaing dengan lulusan dari lembega pendidikan lain.

\section{Rumusan Masalah}

Dari latar belakang masalah di atas, maka perumusan masalah dalam penelitian yaitu :

1. Bagaimanakah kualitas jurusan, kepuasan mahasiswa dan loyalitas mahasiswa jurusan Manajemen Dakwah UIN Ar-Raniry angkatan 2017 sudah baik?

2. Apakah kualitas jurusan berpengaruh terhadap kepuasan mahasiswa jurusan Manajemen Dakwah UIN Ar-Raniry angkatan 2017?

3. Apakah kualitas jurusan berpengaruh terhadap loyalitas mahasiswa jurusan Manajemen Dakwah UIN Ar-Raniry angkatan 2017 ?

4. Apakah kepuasan mahasiswa berpengaruh terhadap loyalitas mahasiswa jurusan Manajemen Dakwah UIN Ar-Raniry angkatan 2017?

5. Apakah kualitas jurusan berpengaruh terhadap loyalitas mahasiswa melalui kepuasan mahasiswa jurusan Manajemen Dakwah UIN Ar-Raniry angkatan $2017 ?$

\section{TINJAUAN PUSTAKA}

\section{Loyalitas}

Dalam penelitian ini mahasiswa dapat dianggap sebagai konsumen karena mahasiswa dapat disamakan sebagai konsumen dalam memperoleh jasa pendidikan yang diberikan oleh pihak kampus, maka peneliti menggunakan teori loyalitas pelanggan sebagai acuan penelitian.

Loyalitas pada jurusan merupakan suatu bentuk perilaku mahasiswa yang mengarah

pada kemungkinan menetap pada jurusan sampai dengan selesai proses perkuliahan, dan memberikan rekomendasi pada pihak lain (Foster\& Cadogan 2000). Loyalitas pelanggan adalah aset yang bernilai strategik, maka peneliti 
Jurnal Bisnis dan Kajian Strategi Manajemen

Volume 2 Nomor 1, 2018

ISSN : 2614-2147

http://jurnal.utu.ac.id/jbkan

perilaku konsumen atau mahasiswa tertarik untuk mengembangkan dan memformulasikan konsep beserta pengukurannya. Masalah pokok yang timbul bagi para peneliti adalah bagaimana mendefinisikan istilah kesetiaan, apakah istilah tersebut dikaitkan dengan perilaku mahasiswa ataukah sikap mahasiswa.Menurut Kotler (2014), menyebutkan bahwa loyalitas pelanggan adalah suatu pembelian ulang yang dilakukan oleh seorang pelanggan karena komitmen pada suatu merek atau perusahaan. Sedangkan menurut Rangkuti,Freddy (2002), Loyalitas konsumen adalah kesetiaan konsumen terhadap perusahaan, merek maupun produk.

Menurut Griffin( 2005) ada beberapa karakteristik dari loyalitas pelanggan diantaranya:

1. Melakukan pembelian secara teratur atau pembelian ulang. pelanggan yang telah melakukan pembelian suatu produk atau jasa sebanyak dua kali atau lebih.

2. Membeli di luar lini produk atau jasa (pembelian antar lini produk). Membeli semua barang atau jasa yang ditawarkan dan mereka butuhkan. Mereka membeli secara teratur, hubungan dengan jenis pelanggan ini sudah kuat dan berlangsung lama serta membuat mereka tidak terpengaruh oleh produk pesaing.

3. Merekomendasikan produk atau jasa kepada orang lain. Membeli barang atau jasa yang ditawarkan dan yang mereka butuhkan, serta melakukan pembelian secara teratur. Selain itu, mereka mendorong orang lain agar membeli barang atau jasa perusahaan tersebut. Secara tidak langsung, mereka telah melakukan pemasaran untuk perusahaan dan membawa konsumen kepada perusahaan.

4. Menunjukkan kekebalan dari daya tarik produk atau jasa sejenis, atau dengan kata lain tidak mudah terpengaruh oleh tarikan pesaing.

\section{Kepuasan}

Keberhasilan sebuah lembaga pendidikan bisa dilihat dari kepuasan yang di rasakan oleh mahasiswa dan alumninya terhadap sistem pendidikan yang ditawarkan, dengan melihat kepuasan mahasiswa kampus bisa mengetahui apakah 
Jurnal Bisnis dan Kajian Strategi Manajemen

Volume 2 Nomor 1, 2018

ISSN : 2614-2147

http://jurnal.utu.ac.id/jbkan

kinerja dari kampus sendiri sudah baik dan sesuai harapan ataukah masih perlu ditingkatkan. Menurut Fandy Tjiptono (2014), kepuasan berasal dari bahasa Latin "Satis" yang berarti cukup baik, memadai dan "Facio" yang berarti melakukan atau membuat. Secara sederhana kepuasan bisa diartikan sebagai upaya pemenuhan sesuatu atau membuat sesuatu memadai.

Menurut Kotler \& Keller (2012)kepuasan adalah perasaan puas atau kecewa seseorang yang dihasilkan dari perbandingan performa produk atau hasil dengan ekspektasi. Jika performanya kurang dari ekspektasi maka mahasiswa akan kecewa dan jika sesuai dengan ekspektasi mahasiswa akan merasa puas. Selanjutnya Kotler dalam buku Sunyoto (2013) juga mengatakan bahwa kepuasan konsumen adalah tingkat perasaan seseorang setelah membandingkan (kinerja atau hasil) yang dirasakan dibandingkan dengan harapannya.

Menurut Fandy Tjiptono (2014) pengukuran kepuasan dilakukan dengan berbagai macam tujuan, di antaranya:

1. Mengidentifikasi keperluan (requirement) konsumen (importantce ratings), yakni aspek-aspek yang dinilai penting oleh konsumen dan mempengaruhi apakah ia puas atau tidak

2. Menentukan tingkat kepuasan konsumen terhadap kinerja organisasi pada aspek-aspek penting.

3. Membandingkan tingkat kepuasan konsumen terhadap perusahaan dengan tingkat kepuasan konsumen terhadap organisasi lain, baik pesaing langsung maupun tidak langsung.

4. Mengidentifikasi PFI (Priorities for Improvement) melalui analisa gap antara skor tingkat kepentingan (importance) dan kepuasan.

5. Mengukur indeks kepuasan konsumen yang bisa menjadi indikator andal dalam memantau kemajuan perkembangan dari waktu ke waktu.

Selanjutnya Kotler\&Keller (2012)mengatakan ada beberapa hal yang dapat mempengaruhi kepuasan pelanggan diantarnya dapat dilihat dari ukuran atau dimensi kepuasan pelanggan yaitu: 
1. Tetap setia, Konsumen yang terpuaskan cenderung akan menjadi setia atau loyal. Konsumen yang puas terhadap produk yang dikonsumsinya akan mempunyai kecenderungan untuk membeli ulang dari produsen yang sama.

2. Membeli produk yang ditawarkan, Keinginan untuk membeli produk atau makanan lain yang ditawarkan karena adanya keinginan untuk mengulang pengalaman yang baik dan menghindari pengalaman yang buruk.

3. Merekomendasikan produk, Kepuasan merupakan faktor yang mendorong adanya komunikasi dari mulut ke mulut (word of mouth communication) yang bersifat positif. Hal ini dapat berupa rekomendasi kepada calon konsumen yang lain dan mengatakan hal-hal yang baik mengenai produk dan perusahaan yang menyediakan produk.

4. Bersedia membayar lebih, Konsumen cenderung menggunakan harga sebagai patokan kepuasan, ketika harga lebih tinggi konsumen cenderung berfikir kualitas menjadi lebih tinggi juga.

5. Memberi masukan, Walaupun kepuasan sudah tercapai, konsumen selalu menginginkan yang lebih lagi, maka konsumen akan memberi masukan atau saran agar keinginan mereka dapat tercapai.

\section{Kualitas jurusan}

Menurut Kotler dan Amstrong (2014) kualitas adalah karakteristikdari produk dalam kemampuan untuk memenuhi kebutuhan-kebutuhan yang telah ditentukan dan bersifat pasti. Menurut Garvin dan A. DaleTimpe (dalam Alma, 2011) kualitas adalah keunggulan yang dimiliki olehproduk tersebut. Kualitas dalam pandangan konsumen adalah hal yangmempunyai ruang lingkup tersendiri yang berbeda dengan kualitas dalam pandangan produsen saat mengeluarkan suatu produk yang biasa dikenal kualitas sebenarnya.

Menurut Kotler (2014), kualitas didefinisikan sebagai keseluruhanciri serta sifat barang dan jasa yang berpengaruh pada kemampuan memenuhi kebutuhan yang dinyatakan maupun yang tersirat. Menurut Tjiptono (2008), kualitas merupakan perpaduan antara sifat dan karakteristik yang menentukan sejauh mana keluaran dapat memenuhi prasyarat kebutuhan pelanggan atau menilai sampai 
Jurnal Bisnis dan Kajian Strategi Manajemen

Volume 2 Nomor 1, 2018

ISSN : 2614-2147

http://jurnal.utu.ac.id/jbkan

seberapa jauh sifat dan karakteristik itu memenuhi kebutuhannya.Zeithaml dalam Kotler (2014) menyatakan bahwa persepsi konsumen terhadap kualitas produk merupakan hasil penambahan informasi, kompetisi dalam kategori produk dan perubahan pengharapan. Disebabkan oleh adanya perubahan produk dan persepsi konsumen.

Menurut Tjiptono (2008), kualitas mencerminkan semua dimensi penawaran produk yang menghasilkan manfaat (benefits) bagi pelanggan. Kualitas suatu produk baik berupa barang atau jasa ditentukan melalui dimensi dimensinya. Dimensi persepsi kualitas produk menurut Tjiptono (2008) adalah :

1. Performance (kinerja), berhubungan dengan karakteristik operasidasar dari sebuah produk.

2. Durability (daya tahan), yang berarti berapa lama atau umur produkyang bersangkutan bertahan sebelum produk tersebut harus diganti.Semakin besar frekuensi pemakaian konsumen terhadap produkmaka semakin besar pula daya produk.

3. Conformance to specifications (kesesuaian dengan spesifikasi),yaitu sejauh mana karakteristik dasar dari sebuah produk memenuhi spesifikasi tertentu dari konsumen atau tidak ditemukannya cacat pada produk. Dalam hal ini antara apa yang telah dibayarkan oleh konsumen sesuai dengan apa yang diharapkan dalam produk tersebut.

4. Features (fitur), adalah karakteristik produk yang dirancang untuk menyempurnakan fungsi produk atau menambah ketertarikan konsumen terhadap produk.

5. Reliability (reliabilitas), adalah probabilitas bahwa produk akan bekerja dengan memuaskan atau tidak dalam periode waktu tertentu. Semakin kecil kemungkinan terjadinya kerusakan maka produk tersebut dapat diandalkan. 
Jurnal Bisnis dan Kajian Strategi Manajemen

Volume 2 Nomor 1, 2018

ISSN : 2614-2147

http://jurnal.utu.ac.id/jbkan

\section{METODE PENELITIAN}

\section{Lokasi dan Objek Penelitian}

Adapun yang menjadi lokasi dari penelitian ini adalah kampus Fakultas Dakwah dan Komunikasi Universitas Islam Negeri Ar-raniry Kota Banda Aceh. Penelitian ini akanmenyajikan pengaruh kualitas jurusan, kepuasan mahasiswa dan loyalitas mahasiswa

\section{Populasi dan Sampel}

Sugiono (2011) menyatakan bahwa populasi adalah wilayah generalisasi yang terdiri atas objek/subjek yang mempunyai kualitas dan karakteristik tertentu yang ditetapkan oleh peneliti untuk dipelajari dan kemudian ditarik kesimpulnnya. Populasi pada penelitian ini adalah seluruh mahasiswa jurusan Manajemen Dakwah UIN Ar-Raniry Banda Aceh yang berjumlah 67 orang.

Sedangkan sampel adalah sebagian dari jumlah dan karakteristik yang dimiliki oleh populasi tersebut (Sugiyono, 2011). Metode penarikan sampel yang akan digunakan dalam penelitian ini adalah metode sensus, yaitu semua anggota populasi dijadikan sebagai sampel (Usman \& Akbar, 2008).

\section{Peralatan Analisis Data}

Analisis data adalah proses penyederhanaan data ke dalam bentuk yang lebih mudah dibaca dan diimplementasikan. Metode yang dipilih untuk menganalisis data harus sesuai dengan pola penelitian dan variabel yang akan diteliti. Penelitian ini menggunakan metode Structural Equation Modeling (SEM) dengan alat penelitian atau software berupa Partial Least Square (PLS). SEM dibagi menjadi dua tipe, yaitu Covarian-based Structural Equation Model (CBSEM) dan Partial Least Square - Structural Equation Modeling (PLS-SEM) (Ghozali dan Latan: 2012). 
Jurnal Bisnis dan Kajian Strategi Manajemen

Volume 2 Nomor 1, 2018

ISSN : 2614-2147

http://jurnal.utu.ac.id/jbkan

\begin{abstract}
ANALISIS HASIL PENELITIAN DAN PEMBAHASAN
Mengevaluasi Reliability dan Average Variance Extracted (AVE)

Kriteria validity dan reliabilitas juga dapat dilihat dari nilai reliabilitas suatukonstruk dan nilai Average Variance Extracted (AVE) dari masing-masing konstruk. Konstruk dikatakan memiliki reliabilitas yang tinggi jika nilainya 0,70 dan AVE berada diatas 0,50. Pada tabel akan disajikan nilai Composite Reliability dan AVE untuk seluruh variabel.
\end{abstract}

Table 2. Composite Reliability AndAverage Variance Extracted

\begin{tabular}{|c|c|c|}
\hline & $\begin{array}{c}\text { Average } \\
\text { Variance } \\
\text { Extracted } \\
\text { (AVE) }\end{array}$ & Romposite \\
& 0.504 & 0.800 \\
\hline Kualitas & 0.578 & 0.810 \\
\hline Kepuasan & 0.514 & 0.837 \\
\hline Loyalitas & & \\
\hline
\end{tabular}

Berdasarkan tabel 1 nilai AVE yang dihasilkan oleh semua konstruk yaitu di atas $>0.50$ sehingga memenuhi persyaratan validitas konvergen. Sedangkan nilai Composite Reliability yang dihasilkan semua konstruk sangat baik yaitu di atas $>0.70$ sehingga dapat disimpulkan bahwa semua indikator konstruk adalah reliabel atau memenuhi uji reabilitas. Secara ringkas hasil evaluasi model pengukuran first order konstruk indikator refleksif di atas dapat dilihat pada tabel di bawah ini:

Table 3. Overview

\begin{tabular}{|l|l|l|c|}
\hline Variabel & R Square & $\begin{array}{l}\text { Cronbachs } \\
\text { Alpha }\end{array}$ & $\begin{array}{l}\text { Commu- } \\
\text { nality }\end{array}$ \\
\hline Kualitas & & 0.712 & 0.504 \\
\hline Kepuasan & 0.502 & 0.703 & 0.578 \\
\hline Loyalitas & 0.665 & 0.756 & 0.514 \\
\hline
\end{tabular}


Jurnal Bisnis dan Kajian Strategi Manajemen

Volume 2 Nomor 1, 2018

ISSN : 2614-2147

http://jurnal.utu.ac.id/jbkan

\section{Analisis dan Pembahasan \\ 1. kualitas jurusan, kepuasan mahasiswa dan loyalitas mahasiswa jurusan Manajemen Dakwah UIN Ar-Raniry angkatan 2017 sudah baik.}

Berdasarkan data statistik pilihan responden diperoleh bahwa rerata nilai skor untuk variabel kualitas jurusan diperoleh nilai 3.126, atau responden mempunyai perespsi yang "cukup baik" terhadap variabel kualitas jurusan. Nilai terendah ditunjukkan oleh indikator "Ruang kuliah yang bagus serta sarana pendukung perkuliahan yang sangat memadai membuat saya betah belajar dijurusan manajemen dakwah" dengan skor 2.552, yang berarti bahwa ruang kuliah yang tidak memadai dengan jumlah mahasiswa dan banyaknya sarana ruang kuliah yang telah rusak. Sedangkan nilai tertinggi ditunjukkan oleh indikator "Jurusan manajemen dakwah konsisten dengan visi dan misi dalam menerapkan kurikulum jurusan" dengan skor 3.507, yang berarti bahwa jurusan manajemen dakwah konsisten dan melenceng dari visi dan misi jurusan dalam mendidik dan mencetak alumni yang kompeten dibidangnya.

Selanjutnya untuk variabel kepuasan mahasiswa diperoleh nilai rerata sebesar 3.641, atau responden memilki persepsi yang "baik" terhadap variabel kepuasan mahasiswa. Nilai terendah ditunjukkan oleh indikator "Saya tidak peduli dan kurang perhatian dengan jurusan lain yang menawarkan kelebihan-kelebihan jurusan mereka" dengan skor 3.358, yang berarti bahwa meskipun banyak tawaran dan godaan jurusan lain mereka tetap merasa puas dengan pendidikan yang diperoleh selama proses perkuliahan. Sedangkan nilai tertinggi ditunjukkan oleh indikator "Saya merasa puas belajar pada jurusan ini, dan saya akan tetap melanjutkan perkuliahan pada jurusan ini" dengan skor 3.836, yang berarti bahwa mahasiswa terpuaskan dengan pendidikan yang diberikan oleh jurusan Manajemen Dakwah.

Pada variabel terakhir yaitu loyalitas mahasiswa diperoleh diperoleh nilai rerata dengan skor 3.594, atau responden mempunyai persepsi yang "baik" terhadap variabel loyalitas mahasiswa. Adapun nilai terendah ditunjukkan oleh indikator "Saya sering memberikan ide-ide baru dan masukan kepada jurusan" 
Jurnal Bisnis dan Kajian Strategi Manajemen

Volume 2 Nomor 1, 2018

ISSN : 2614-2147

http://jurnal.utu.ac.id/jbkan

dengan skor 2.925, yang berarti bahwa mahasiswa akan berkurang rasa loyalitasnya terhadap jurusan apabila tidak memliki kesempatan dalam memberikan pendapatnya untuk memajukan jurusan, karena semakin tinggi rasa loyalitas mahasiswa maka akan semakin tinggi pula rasa memiliki jurusan, namun apabila loyalitas menurun maka mahasiswa akan bersikap apatis dan tidak ada keinginan untuk bersama-sama memajukan jurusan. Sedangkan nilai tertinggi ditunjukkan oleh indikator "Saya akan berkomitmen melanjutkan kuliah saya dijurusan manajemen dakwah sampai dengan selesai” dengan skor 4.104, yang berarti bahwa mahasiswa jurusan manajemen dakwah berkomitmen untuk melanjutkan kuliahnya hingga selesai.

\section{Pengaruh kualitas jurusan terhadap kepuasan mahasiswa jurusan Manajemen Dakwah UIN Ar-Raniry angkatan 2017}

Berdasarkan hasil perhitungan statistik, dapat disimpulkan bahwa konstruk kualitas jurusan berpengaruh positif dan signifikan terhadap konstruk kepuasan mahasiswa secara langsung. Hal ini dapat dilihat dari nilai $t$-statistic yanglebih besar dari 1.960 yakni sebesar 15.639 dengan nilai P values 0.000. Dari hasil pengujian dapat disimpulkan bahwa semakin baik kualitas suatu produk atau jasa yang diciptakan atau diberikan maka akan semakin tinggi tingkat kepuasan yang diperolah oleh pelanggan. Tingginya kualitas sebuah jurusan dapat ditentukan oleh kinerja jurusan itu sendiri seperti sistem perkuliahan yang baik, pelayanan akademik yang baik, dosen yang berkualitas, kelengkapan sarana dan prasarana serta adanya jaminan masa depan bagi alumni mencari pekerjaan atau mengembangkan keahliaan dalam berwirausaha.

\section{Pengaruh kualitas jurusan terhadap loyalitas mahasiswa jurusan Manajemen Dakwah UIN Ar-Raniry angkatan 2017.}

Hasil pengujian selanjutnya menunjukkan bahwa pengaruh variabel kualitas jurusan terhadap loyalitas mahasiswa menunjukkan nilai t sebesar 14.319. Nilai tersebut lebih besar dari t tabel 1.960 dengan nilai P values 0,000 . Hasil ini berarti bahwa kualitas jurusan memiliki pengaruh yang positif dan signifikan 
Jurnal Bisnis dan Kajian Strategi Manajemen

Volume 2 Nomor 1, 2018

ISSN : 2614-2147

http://jurnal.utu.ac.id/jbkan

terhadap loyalitas mahasiswa, yang berarti bahwa kualitas jurusan yang baik akan berdampak pada meningkatnya loyalitas mahasiswa terhadap jurusan, dimana mahasiswa yang memperoleh pendidikan yang bagus dari jurusan, kelengkapan sarana dan prasarana pendukung belajar serta pelayanan akademik yang baik akan berdampak pada kemauan mahasiswa untuk bertahan dan menyelesaikan proses perkuliahan.

\section{Pengaruh kepuasan mahasiswa terhadap loyalitas mahasiswa jurusan Manajemen Dakwah UIN Ar-Raniry angkatan 2017.}

Berdasarkan hasil perhitungan statistik, dapat disimpulkan bahwa konstruk kepuasan mahasiswa berpengaruh positif dan signifikan terhadap konstruk loyalitas mahasiswa secara langsung. Hal ini dapat dilihat dari nilai t-statistic yanglebih besar dari 1.960 yakni sebesar 22.281 dengan nilai $\mathrm{P}$ values 0.000 . Hasil pengujian ini berarti bahwa semakin tinggi tingkat kepuasan mahasiswa terhadap jurusan maka semakin tinggi pula loyalitas mahasiswa terhadap jurusan. Hal ini dikarenakan pihak jurusan berusaha untuk memenuhi harapan- harapan yang diinginkan oleh mahasiswa, semakin banyak masukan yang direalisasikan oleh pihak kampus maka tingkat kepuasan mahasiswa juga akan semakin tinggi, yang pada akhirnya dapat meminimalisir tingkat perpindahan mahasiswa pada jurusan maupun universitas lain juga akan semakin rendah atau berkurang. Tetapijuga bisa terjadi sebaliknya. Jika ternyata mahasiswa merasa tidak bisa mendapatkan yang sesuai atau yang diinginkan maka mahasiswa akan kehilangan loyalitasnya dikarena kecewa atau dikarenakan banyak alternatif jurusan atau universitas lain yang menawarkan berbagaikeunggulan dibidangnya. 
Jurnal Bisnis dan Kajian Strategi Manajemen

Volume 2 Nomor 1, 2018

ISSN : 2614-2147

http://jurnal.utu.ac.id/jbkan

\section{Pengaruh kualitas jurusan terhadap loyalitas mahasiswa melalui kepuasan mahasiswa jurusan Manajemen Dakwah UIN Ar-Raniry angkatan 2017.}

Table 4. Pengaruh kualitas jurusan terhadap loyalitas mahasiswa melalui kepuasan mahasiswa

\begin{tabular}{|c|c|c|c|c|c|}
\hline Variabel & $\begin{array}{c}\text { Original } \\
\text { Sample } \\
(\mathbf{O})\end{array}$ & $\begin{array}{c}\text { Sample } \\
\text { Mean } \\
(\mathbf{M})\end{array}$ & $\begin{array}{c}\text { Standard } \\
\text { Error } \\
\mathbf{( S T E R R )}\end{array}$ & $\begin{array}{c}\text { T } \\
\text { Statistics } \\
(\mathbf{O} / \mathbf{S T E R} \\
\mathbf{R} \mid \mathbf{)}\end{array}$ & P Values \\
\hline $\begin{array}{c}\text { Kualitas -> } \\
\text { Kepuasan }\end{array}$ & 0.714 & 0.727 & 0.049 & 14.658 & 0.000 \\
\hline $\begin{array}{c}\text { Kualitas -> } \\
\text { Loyalitas }\end{array}$ & 0.242 & 0.259 & 0.141 & 1.711 & 0.092 \\
\hline $\begin{array}{c}\text { Kepuasan -> } \\
\text { Loyalitas }\end{array}$ & 0.632 & 0.631 & 0.128 & 4.935 & 0.000 \\
\hline
\end{tabular}

Selanjutnya untuk pengujian pengaruh tidak langsung variabel kualitas jurusan terhadap loyalitas mahasiswa melalui kepuasan mahasiswa dilakukan dengan terlebih dahulu mengetahui hasil pengujian terhadap pengaruh kepuasan mahasiswa terhadap loyalitas mahasiswa. Pengujian pengaruh mediasi dilakukan dengan menggunakan rumus Sobel.

Hasil pengujian pengaruh kepuasan mahasiswa terhadap loyalitas mahasiswa menunjukkan nilai koefisien jalur sebesar 0.632. Nilai t diperoleh sebesar 4.935. Nilai tersebut lebih besar dari t tabel 1,960. Hasil ini berarti bahwa kepuasa mahasiswa memiliki pengaruh positif signifikan terhadap loyalitas mahasiswa.

Pengujian terhadap pengaruh mediasi antar variabel intervening dengan variabel dependen dilakukan dengan perhitungan rumus Sobel. Hasil dari kedua pengujian diringkas sebagai berikut :

$$
\begin{array}{ll}
\text { Os } 1=0.714 & \text { Os2 }=0.632 \\
\text { Se1 }=0.049 & \text { Se2 }=0.128
\end{array}
$$

Besarnya koefisien tidak langsung variabel kualitas jurusan terhadap loyalitas mahasiswa merupakan perkalian dari pengaruh variabel kualitas jurusan 
Jurnal Bisnis dan Kajian Strategi Manajemen

Volume 2 Nomor 1, 2018

ISSN : 2614-2147

http://jurnal.utu.ac.id/jbkan

terhadap variabel kepuasan mahasiswa terhadap loyalitas mahasiswa, sehingga diperoleh sebagai berikut :

$$
\begin{aligned}
\text { Os12 } & =\text { Os1 .Os } 2 \\
& =(0.714)(0.632) \\
& =0.451
\end{aligned}
$$

Besarnya standard error tidak langsung kualitas jurusan terhadap loyalitas mahasiswa merupakan perkalian dari pengaruh kualitas jurusan terhadap kepuasan mahasiswa dengan kepuasan mahasiswa terhadap loyalitas mahasiswa, sehingga diperoleh sebagai berikut :

$$
\begin{aligned}
\mathrm{Se} 12= & \sqrt{ } \mathrm{Os} 1^{2} . \mathrm{Se} 2^{2}+\mathrm{Os} 2^{2} \cdot \mathrm{Se} 1^{2}+\mathrm{Se} 1^{2} \cdot \mathrm{Se} 2^{2} \\
= & \sqrt{ }(0.714)^{2}(0.128)^{2}+(0.632)^{2}(0.049)^{2}+(0.049)^{2}(0.128)^{2} \\
& =\sqrt{ } 0,00899+0,00095+0,00003 \\
& =\sqrt{ } 0,0099 \\
& =0,099
\end{aligned}
$$

Dengan demikian nilai uji t diperoleh sebagai berikut :

$$
\mathrm{t}=\frac{o s 12}{\operatorname{se} 12}=\frac{0.451}{0.099}=4.555
$$

Nilai t sebesar 4.555 tersebut lebih besar dari 1,960 yang berarti bahwa parameter mediasi tersebut signifikan. Maka dengan demikian model pengaruh tidak langsung dari variabel kualitas jurusan terhadap loyalitas mahasiswa melalui kepuasan mahasiswa secara tidak langsung berpengaruh secara signifikan.

Dengan demikian dapat disimpulkan bahwa sebuah jurusan yang memiliki kualitas yang baik akan menghasilkan kepuasan yang mahasiswa yang tinggi dalam proses belajar dan juga dalam mendapatkan pelayanan yang diberikan oleh kampus dibidang administrasi, kemudian yang pada akhirnya akan berdampak pada tingginya loyalitas mahaiswa terhadap jurusan. Tingginya loyalitas mahasiswa akan berdampak pada menurunnya perpindahan mahasiswa kepada jurusan maupun universitas lain, selain itu dengan tingginya loyalitas mahasiswa juga akan berdampak positif pada pengenalan dan rekomendasi mahasiswa terhadap calon mahasiswa baru ditahun ajaran yang akan datang. 
http://jurnal.utu.ac.id/jbkan

\section{KESIMPULAN DAN SARAN}

\section{Kesimpulan}

1. Berdasarkan data statistik pilihan responden diperoleh bahwa rerata nilai skor untuk variabel kualitas jurusan diperoleh nilai 3.126, atau responden mempunyai perespsi yang "cukup baik" terhadap variabel kualitas jurusan. Selanjutnya untuk variabel kepuasan mahasiswa diperoleh nilai rerata sebesar 3.641, atau responden memilki persepsi yang "baik" terhadap variabel kepuasan mahasiswa. Pada variabel terakhir yaitu loyalitas mahasiswa diperoleh diperoleh nilai rerata dengan skor 3.594, atau responden mempunyai persepsi yang "baik" terhadap variabel loyalitas mahasiswa.

2. Dari penelitian yang telah dilakukan dapat disimpulkan bahwa kualitas jurusan berpengaruh terhadap kepuasan mahaiswa secara signifikan dengan nilai t sebesar 15.639, lebih besar dari nilai t table yaitu 1.960 dan dengan nilai $\mathrm{p}$ values yaitu 0.000 .

3. Dari penelitian yang telah dilakukan dapat disimpulkan bahwa kualitas jurusan berpengaruh terhadap loyalitas mahasiswa secara signifikan dengan nilai t sebesar 14.319 , lebih besar dari nilai t table yaitu 1.960 dan dengan nilai $p$ values yaitu 0.000 .

4. Dari penelitian yang telah dilakukan dapat disimpulkan bahwa kepuasan mahasiswa berpengaruh terhadap loyalitas mahasiswa secara signifikan dengan nilai t sebesar 22.281, lebih besar dari nilai t table yaitu 1.960 dan dengan nilai $\mathrm{p}$ values yaitu 0.000 .

5. Dari hasilpenelitian yang telah dilakukan dapat disimpulkan bahwa kualitas jurusan berpengaruh secara signifikan terhadap loyalitas mahasiswa melalui kepuasan mahasiswa dengan nilai $\mathrm{t}$ sebesar 4.555, yang berarti bahwa semakin baik kualitas suatu jurusan maka semakin tinggi tingkat kepuasan yang dimiliki oleh mahasiswa, kemudian yang pada akhirnya akan berdampak pada tingginya loyalitas mahasiswa, mereka akan bertahan hingga selesai bahkan akan merekomendasikan jurusan pada calon mahasiswa baru nantinya. 
http://jurnal.utu.ac.id/jbkan

\section{Saran}

1. Kualitas jurusan merupakan faktor penting dalam dunia pendidikan, karean dengan tingginya kualitas suatu jurusan maka akan mencetak sumber daya manusia yang berkompeten, mandiri dan beretika. Oleh karena itu, diharapkan kepada jurusan manajemen dakwah UIN Ar-Raniry banda aceh agar terus mengembangkan sumber daya manusia yang dimiliki baik dari segi dosen maupun petugas administrasi dalam memberikan pelayanan kepada mahsiswa.

2. Kurangnya jumlah dosen tetap yang berlatar belakang ilmu manajemen menjadi salah satu hambatan dalam proses mengajar, karena banyak dosen tetap yang mengajar bukan pada bidangnya. oleh karena itu, diharapkan kepada jurusan manajemen dakwah agar menambah jumlah dosen tetap yang berlatar belakang pendidikan ilmu manajemen.

3. Banyaknya fasilitas pendukung belajaryang rusak dapat mengakibatnya terhambatnya proses belajar mengajar, oleh karena itu diharapkan kepada pihak kampus agar segera memperbaiki atau mengganti fasilitas pendukung tersebut agar terlaksananya proses belajar mengajar yang nyaman dan menyenangkan.

4. Akreditas kampus juga dipengaruhi oleh tingkat keberhasilan alumni dalam menyalurkan ilmu dan keahlian yang dimilki, oleh karena itu disarankan kepada jurusan manajemen dakwah UIN Ar-Raniry Banda Aceh agar memperbanyak kerjasama baik dengan pemerintah maupun swasta untuk memperkenalkan dan menyalurkan alumni di dunia kerja. 


\section{DAFTAR PUSTAKA}

Agung, Ken Hermanto 2006, Analisis Pengaruh Kualitas Layanan, Komitmen, dan

Kepercayaan Terhadap Loyalitas Konsumen (Studi Kasus Pada Nasabah Tabungan

SIMPEDA Bank JATENG), Tesis, Magister Manajemen, Universitas Diponegoro.

Alma, Buchari, 2011,Manajemen Pemasaran dan Pemasaran Jasa. Bandung: Penerbit Alfabeta.

Aloysia dan Yuliana. 2004. Faktor-Faktor yang Mempengaruhi Audit Delay di Indonesia. Jurnal Ekonomi dan Bisinis Vol.16 No.2, 135-146.

Brian, F. Foster, John W. Cadogan, 2000, Relationship selling and Customer Loyalty: an empirical investigation,Marketing Intelligence \& Planning, Vol. 18 No.4, pp. 185-199.

Danang Sunyoto, 2013,Perilaku Konsumen (Panduan Riset Sederhana Untuk MengenaliKonsumen), Yogyakarta: CAPS

Griffin, Jill. 2005.2 Customer Loyality: Menumbuhkan dan Mempertahankan Kesetiaan Pelanggan. Diterjemahkan: Dwi Kartini Yahya. Jakarta: Erlangga

Imam GhozalidanHengkyLatan, (2012), "Partial Least Squares: Konsep, Teknik dan Aplikasi Menggunakan Program SmartPLS 2.0 M3, Semarang: Badan Penerbit Universitas Diponegoro.

Kotler, \& Keller, 2012,Manajemen Pemasaran. Jakarta: Erlanga.

Kotler, Philip dan Amstrong, Gary, 2014, Principles of Marketin, 12th Edition, Jilid 1 Terjemahan Bob Sabran Jakarta : Erlangga.

Rangkuti, Freddy, 2002, Measuring Customer Satisfaction, Jakarta: Penerbit PT Gramedia Pustaka Utama.

Sugiono, 2011,Statistik Untuk Penelitian. Bandung: Alfabeta

Sutisna. 2003. Perilaku Konsumen dan Komunikasi Pemasaran. Bandung : PT Remaja Rosdakarya.

Tjiptono, \& Fandy, 2014,Strategi Pemasaran. Yogyakarta: Graha Ilmu.

Tjiptono, 2008, Total Quality Manajemen, Yogyakarta:Andi Offset.

Usman, H dan Akbar. 2008. Pengantar Statistik, Edisi Kedua. Jakarta: Bumi Aksara

Yuliana, 2004,Manjemen Pendidikan, Yogyakarta: Aditya Media,

Zeithaml, Valarie A. Mry Jo Bitner, 2000, Services Marketing: Integrating Customer Focus Across The Firm, Second Edition Hill. . New York: McGraw 